\title{
ASSESSMENT OF BACTERIAL LEAF BLIGHT DISEASE RESISTANCE OF INDONESIAN RICE GERMPLASMS USING SSR MARKERS
}

\author{
Fatimah*, Tasliah, Joko Prasetiyono, Mahrup \\ Indonesian Center for Agricultural Biotechnology and Genetic Resources Research and Development, \\ Indonesia.
}

\begin{abstract}
Bacterial leaf blight (BLB) caused by Xanthomonas oryzae pv. oryzae (Xoo) is a serious disease in rice plants worldwide. Yield losses caused by Xoo can be as high as $50 \%$ in some parts of Asia. Xa7 gene can potentially confer a broad resistance to BLB. Evaluation of disease resistance characteristics in early breeding generations of rice is important to develop varieties with better resistance. This study reports the evaluation of 167 Indonesian rice germplasms against three BLB isolates/pathotypes in a green house setting and the genotyping of 56 Indonesian rice germplasm using 12 SSR markers linked to Xa7 BLB resistance gene. The majority of the indigenous rice germplasms was found to be susceptible to three BLB isolates/pathotypes tested. Sate Liko from Bantul, Yogyakarta, Horeg from Cirebon, West Java and Sijem from Malang, East Java revealed consistent resistance to three isolates/pathotypes tested based on BLB evaluation in a greenhouse, UPGMA analysis, and genotyping. Pathotype XII displayed more virulence to Indonesian rice varieties tested compared to pathotypes VI and V. The association analysis using the General linear model identified six markers associated with BLB resistance and two markers were highly associated (RM20589 and RM20590). This information will be useful for future studies of BLB resistance in rice plants.
\end{abstract}

Keywords: Bacterial leaf blight, Molecular marker, SSR, Xanthomonas oryzae, Xa7

*Corresponding author:

Indonesian Center for Agricultural Biotechnology and Genetic Resources Research and Development (ICABIOGRAD), Jl. Tentara Pelajar No.3A Cimanggu, Bogor 16111.

Tel. +62-21-8754587, Fax. +62-21-87754588

E-mail. fatimahsuw@gmail.com

\section{Introduction}

BLB caused by Xanthomonas oryzae pv. Oryzae (Xoo), is a serious disease affecting rice plants in tropical lowland environment. This disease is not only widespread throughout Asia but also occurring in Australia, the United States and in several rice growing countries of Latin America and Africa. Yield losses caused by Xoo typically range from 20 to $30 \%$ and can be as high as $50 \%$ in some parts of Asia (Adhikari et al., 1995).

Hifni and Kardin (1998) reported that there are 12 pathotypes of Xoo based on IRRI differential varieties. Pathotype V, the most dominant pathotype $(46.23 \%)$, can overcome at least seven virulence genes (Xa1, Xa2, Xa3, $X a 4, X a 10, X a 11$, and Xa14), while Pathotype VI as the second dominant pathotype $(11,32 \%)$ can overcome at least eight virulence genes
(Xa1, Xa2, Xa3, Xa4, Xa10, Xa11, Xa14 and Xa21). Furthermore, the most virulent one, Pathotype XII can overcome at least 10 virulence genes (Xa1,Xa2, Xa3, Xa4, Xa5, $X a 7, X a 10, X a 11, X a 14$, and Xa21).

Genetic diversity is a key factor in sustaining agricultural productivity. In order to preserve and make this diversity available for crop improvement, tremendous efforts have been made in the collection, maintenance, and classical characterization of germplasm. Generating a new crop variety with certain desirable traits requires a germplasm collection with a wide genetic diversity. The germplasm collection may be of local, introduced, or breed varieties (Syam and Hermanto, 1995).

In order to develop BLB resistant varieties, selection of appropriate donor parents that show a broad spectrum of resistance to other Xoo pathotypes is important for the breeding 
program. Thus, evaluation of introduced and indigenous rice germplasms for their BLB resistance profile is one of the primary tasks for rice genetic resources management and utilization.

Molecular markers have shown a tremendous potential for characterizing genetic diversity. The availability of DNA markers linked to genes for BLB resistance would accelerate breeding programs. Furthermore, PCR-based markers closely linked to BLB resistance genes would be very useful for an efficient marker-assisted selection.

Recently, 45 BLB resistance genes (Xa) from cultivated rice and wild species have been identified and mapped (Neelam et al., 2020). In Indonesia, $x a 5, X a 7$, and $X a 21$ are relatively effective against the majority of the Xoo isolates/pathotypes, so that these resistance genes can be incorporated into our rice breeding program (Hifni and Kardin, 1998; Tasliah et al., 2013; Fatimah et al., 2014). Due to the lower percentage of Xoo pathotypes having the ability to overcome $\mathrm{Xa}$, subsequent addition of virulence genes that can overcome $\mathrm{Xa} 7$ into the Xoo population occurred after the integration of the virulence genes that can overcome $x a 5$ and Xa21 (Hifni and Kardin, 1998).

Located in chromosome $6, X a 7$ is a dominant resistance gene directed against Xoo and was originally identified in the rice cultivar DV85, IRRI accession number 8839 (Sidhu et al., 1978). The gene was transferred to cultivar IR24 and near isogenic line IRBB7, where $\mathrm{Xa} 7$ was integrated by recurrent backcrossing (Ogawa et al., 1991). Xa7 is an example of an R-gene that is directed against an avirulence gene family and is a potential source of broad resistance to BLB affecting rice plants (Cruz et al., 2000).

The objective of this study is to evaluate BLB resistance of 167 Indonesian rice germplasms in a green house against three BLB isolates/pathotypes and to perform genotyping on 56 Indonesian rice germplasms using 12 SSR markers linked to $\mathrm{Xa} 7 \mathrm{BLB}$ resistance gene. These information will be useful for future studies on BLB resistance in rice plants.

\section{Materials and Methods}

Plant Materials. One hundred and sixty-five accessions of Indonesian rice germplasm provided by Indonesian Center for Agricultural Biotechnology and Genetic Resources Research and Development (ICABIOGRAD) and two IRRI varieties were used for BLB resistance evaluation. IRBB7 and Conde for containing $\mathrm{Xa} 7$ resistance gene were used as the resistant controls and IR24 and Kencana Bali as a susceptible control (Table 1). The $\mathrm{Xoo}$ isolates/pathotypes provided by ICABIOGRAD were used for BLB evaluation (Tasliah et al., 2013) (Table 2).

\section{Disease Assesment of Rice Germplasms.}

Rice plants were grown under greenhouse conditions. These rice germplasms were first sown in plastic boxes, and 14 days later, the seedlings were transplanted into a container box containing natural paddy soil. The experimental units consisted of nine rows with a spacing of $6 \mathrm{~cm}$. Each rice germplasm was transplanted in one row of five plants. The seedlings were watered twice a day using a sprinkle system to maintain the proper humidity and the optimum conditions for the growth of Xoo.

The bacterial suspension for inoculation was prepared using the two-day old culture of each isolate in $20 \mathrm{ml}$ of sterilized distilled water adjusted of $10^{8} \mathrm{CFU} / \mathrm{ml}$. To test the virulence of the strains, the fully expanded leaves were inoculated by the leaf cutting method (Kauffman et al., 1973).

Bacterial inoculation was done when rice plants were 40 days old. Evaluation for resistance of each germplasm was done at 14 DAI (days after inoculation) according to the Standard Evaluation System for Rice. Ten randomly selected leaf clippings of each lineisolate combination were rated for their percent ratio of lesion length to entire leaf length. The symptoms were scored as resistant if the average attack intensity was $25 \%$ or less (score $1-4$ ) and as susceptible if the average attack intensity was greater than $25 \%$ (score 5 to 9) (Chaudry, 1996).

\section{Molecular Marker Analysis.}

SSR genotyping of twelve SSR markers (Table 3) on chromosome 6 that are linked to $\mathrm{Xa} 7$ as previously reported by Chen et al. (2008) were employed to identify the $\mathrm{Xa} 7$ gene on randomly selected 56 rice accession (no.111-167), which included the resistant and susceptible accessions. Total genomic DNA was extracted using young leaves at seedling 
stage as described previously (Dellaporta, 1983) for each individual accession. Genomic DNA concentration was measured by spectrophotometer and the DNA samples were diluted to $10 \mathrm{ng} / \mathrm{ul}$ using sterilized distilled water and stored in microfuge tubes at $4{ }^{\circ} \mathrm{C}$ for further use.

Table 1. List of rice germplasms used in this study

\begin{tabular}{|c|c|c|c|c|c|c|c|}
\hline \multirow{2}{*}{\multicolumn{4}{|c|}{$\begin{array}{l}\text { stage as described previously (Dellaporta, } \\
\text { 1983) for each individual accession. Genomic }\end{array}$}} & \\
\hline & & & & No. & Acc.No. & $\begin{array}{l}\text { Accession } \\
\text { Name }\end{array}$ & Origin \\
\hline \multirow{3}{*}{\multicolumn{4}{|c|}{$\begin{array}{l}\text { DNA concentration was measured by } \\
\text { spectrophotometer and the DNA samples were } \\
\text { diluted to } 10 \mathrm{ng} / \mathrm{ul} \text { using sterilized distilled } \\
\text { water and stored in microfuge tubes at } 4^{\circ} \mathrm{C} \text { for } \\
\text { further use. }\end{array}$}} & 42 & 12571 & Gondok & $\begin{array}{l}\text { Tanah Datar, West } \\
\text { Sumatera }\end{array}$ \\
\hline & & & & 43 & 12574 & Laila & $\begin{array}{l}\text { Tanah Datar, West } \\
\text { Sumatera }\end{array}$ \\
\hline & & & & 44 & 12674 & $\begin{array}{l}\text { Padi Belanak } \\
\text { Kosambi }\end{array}$ & Bangli, Bali \\
\hline \multirow{2}{*}{\multicolumn{4}{|c|}{$\begin{array}{l}\text { Table 1. List of rice germplasms used in this } \\
\text { study }\end{array}$}} & 45 & 12968 & Padi Jambai & Kampar, Riau \\
\hline & & & & 46 & 14866 & Terotel & $\begin{array}{l}\text { Sawahlunto, West } \\
\text { Sumatera }\end{array}$ \\
\hline \multirow{2}{*}{ No. } & \multirow{2}{*}{ Acc.No. } & Accession & \multirow{2}{*}{ Origin } & 47 & 14895 & Wuri Bura & West Nusa Tenggara \\
\hline & & Name & & 48 & 14903 & Samada & West Nusa Tenggara \\
\hline 1 & 1430 & $\begin{array}{l}\text { Putih Ampat } \\
\text { Angkek }\end{array}$ & West Sumatera & 49 & 14915 & Dendak & $\begin{array}{l}\text { Sumbawa, West Nusa } \\
\text { Tenggara }\end{array}$ \\
\hline 2 & 3983 & Reli & West Kalimantan & 50 & 14986 & Lumbuk & Central Java \\
\hline 3 & 3995 & Seng Kumang & West Kalimantan & 51 & 18960 & Secangkir & South Kalimantan \\
\hline 4 & 3996 & Mingkai & West Kalimantan & 52 & 19100 & Thapora & Philippine \\
\hline 5 & 4043 & Rijah & Central Java & 53 & 19101 & Tuma & Philippine \\
\hline 6 & 4050 & Aluh Kuranji & West Sumatera & 54 & 10125 & Seratus Malam & Kodya Bogor, West \\
\hline 7 & 4071 & Kuning Biaro & West Sumatera & 54 & 19125 & Seratus Malam & Java \\
\hline 8 & 4084 & Gondak Kiah & West Sumatera & 55 & 19228 & Brown Gora & Philippine \\
\hline \multirow{2}{*}{9} & \multirow{2}{*}{4141} & Si Rendah & \multirow{2}{*}{ West Sumatera } & 56 & 19229 & Dular & Philippine \\
\hline & & Cogok & & 57 & 19250 & Sibentar & Karo, North Sumatera \\
\hline 10 & 4206 & Tromas & Central Java & 58 & 19251 & Siremut & Karo, North Sumatera \\
\hline 11 & 4213 & Goter & East Java & \multirow{2}{*}{59} & \multirow{2}{*}{19661} & & Kodya Bogor, West \\
\hline 12 & 4214 & Untup & East Java & & & Buhbolon & Java \\
\hline 13 & 4256 & Mayor & East Java & 60 & & Danau $\Delta$ tas & Kodya Bogor, West \\
\hline 14 & 4305 & Baliman Putih & South Kalimantan & 60 & $196 / 3$ & Danau Atas & Java \\
\hline 15 & 4310 & Biduin & South Kalimantan & & & & Kodya Bogor, West \\
\hline 16 & 4311 & Randah Pala & South Kalimantan & 61 & 19677 & Poso & Java \\
\hline 17 & 4315 & Lalantik & South Kalimantan & 62 & 19701 & Engkoran & West Kalimantan \\
\hline 11 & 4315 & Bamban & & 63 & 19703 & Bauno & Sanggau, West \\
\hline 18 & 4316 & Raden Pulatar & South Kalimantan & 63 & $19 / 03$ & Baung & Kalimantan \\
\hline 19 & 4324 & Siam Parapuk & South Kalimantan & & 10708 & Baniar Sawan & Sanggau, West \\
\hline 20 & 4491 & Sara Kasa & Central Sulawesi & 64 & 19708 & Banjar Sawan & Kalimantan \\
\hline 21 & 5593 & Pingkan & Central Sulawesi & 65 & 19710 & Kail & West Kalimantan \\
\hline 22 & 5594 & Pimpin & Central Sulawesi & & & Payak & Sambas, West \\
\hline 23 & 6859 & Bengkongang & Central Java & 66 & 19757 & Tembakau & Kalimantan \\
\hline 24 & 6967 & Cicih Buleleng & Bali & & & Pihun & Kapuas Hulu, West \\
\hline 25 & 7237 & Angkong & West Java & 67 & 19768 & Ribun & Kalimantan \\
\hline 26 & 9151 & Padi Book & South East Sulawesi & 68 & & & Kapuas Hulu, West \\
\hline 27 & 9154 & Longandobu & South East Sulawesi & 68 & 19771 & Bont1 & Kalimantan \\
\hline 28 & 9155 & Padi Ana-Ana & South East Sulawesi & 69 & 20227 & Idi & Aceh \\
\hline 29 & 9173 & Anambar & South East Sulawesi & 70 & 20228 & Syair & Aceh \\
\hline 30 & 9186 & Wulu Mata & South East Sulawesi & 71 & 20241 & Rangkoh & Aceh \\
\hline 31 & 9458 & Ingsa Cendana & Bali & 72 & 20244 & Si Reguek & Aceh \\
\hline 32 & 9467 & Ingsa Bondol & Bali & 73 & 20245 & Putih Panjah & Aceh \\
\hline 33 & 10613 & Banja Ili & South East Sulawesi & 74 & 20256 & Bho & Aceh \\
\hline 34 & 12270 & Rejuno & Tanjung Jabung, Jambi & 75 & 20513 & Lemo & Central Kalimantan \\
\hline & & & Pekalongan, Central & 76 & 20673 & Si Motung & North Sumatera \\
\hline 35 & 12307 & Abang & Java & 77 & 20678 & Si Anak Bogor & North Sumatera \\
\hline 36 & & Segon & Kodya Bogor, West & 78 & 20679 & Si Lotik & North Sumatera \\
\hline 36 & 12308 & Borondol & Java & & & Si Pulo & \\
\hline 37 & 12335 & Mojang & Garut, West Java & 79 & 20682 & Angkola & North Sumatera \\
\hline 38 & 12338 & Rangkong & Tangerang, West Java & 80 & 20683 & Si Pulo Manda & North Sumatera \\
\hline 39 & 12344 & $\begin{array}{l}\text { Cere } \\
\text { Mentik/Toray }\end{array}$ & Purwakarta, West Java & 81 & 20688 & $\begin{array}{l}\text { iling } \\
\text { Putri Manis }\end{array}$ & 1 vortil sumatera \\
\hline 40 & 12352 & Hawara Batu & Cianjur, West Java & 82 & 20694 & Kuala Deli & North Sumatera \\
\hline 41 & 12368 & Muncang & Cianjur, West Java & 83 & 20708 & Ramos Batu & North Sumatera \\
\hline
\end{tabular}




\begin{tabular}{|c|c|c|c|c|c|c|c|}
\hline No. & Acc.No. & $\begin{array}{l}\text { Accession } \\
\text { Name }\end{array}$ & Origin & No. & Acc.No. & $\begin{array}{l}\text { Accession } \\
\text { Name }\end{array}$ & Origin \\
\hline 84 & 20746 & Mama Laka & East Nusa Tenggara & \multirow{2}{*}{130} & \multirow{2}{*}{12564} & \multirow{2}{*}{ Kodok Putih } & Tanah Datar, West \\
\hline 85 & 20759 & Wajo Kuning & East Nusa Tenggara & & & & Sumatera \\
\hline 86 & 20765 & Sera & East Nusa Tenggara & \multirow{2}{*}{131} & \multirow{2}{*}{12723} & \multirow{2}{*}{$\begin{array}{l}\text { Cempo Abang } \\
\text { ner }\end{array}$} & \multirow{2}{*}{ Cirebon, West java } \\
\hline 87 & 20766 & Keakubi & East Nusa Tenggara & & & & \\
\hline 88 & 20819 & Sehan & North Maluku & \multirow{2}{*}{132} & \multirow{2}{*}{13102} & \multirow{2}{*}{ Teratai } & \multirow{3}{*}{$\begin{array}{l}\text { Ketapang, West } \\
\text { Kalimantan } \\
\text { South Sulawesi }\end{array}$} \\
\hline 89 & 20848 & Ardas & North Sulawesi & & & & \\
\hline 90 & 20851 & Apel & North Sulawesi & 133 & 15005 & Banda & \\
\hline \multirow{2}{*}{91} & \multirow{2}{*}{20878} & Ndangan & \multirow{2}{*}{ South Sulawesi } & \multirow{3}{*}{$\begin{array}{l}134 \\
135\end{array}$} & 3571 & Betonan & \multirow{4}{*}{$\begin{array}{l}\text { East Java } \\
50 \text { Kota, West } \\
\text { Sumatera } \\
\text { Tanah datar, West } \\
\text { Sumatera }\end{array}$} \\
\hline & & Cantik 1 & & & & $\begin{array}{l}\text { Betonan } \\
\text { Lumut }\end{array}$ & \\
\hline 92 & 20906 & Lokal buntu & South Sulawesi & & & \multirow{2}{*}{$\begin{array}{l}\text { Sunting } \\
\text { Beringin }\end{array}$} & \\
\hline 93 & 20908 & $\begin{array}{l}\text { Sangala } 2 \\
\text { Pare Pulunglia }\end{array}$ & South Sulawesi & 136 & 4087 & & \\
\hline 94 & 20962 & Cere Gelas & West Java & \multirow{2}{*}{137} & & Siak Simnur & Sambas, West \\
\hline 95 & 20967 & $\begin{array}{l}\text { Kembang } \\
\text { Ading }\end{array}$ & West Java & & 4137 & Bendang Bujur & $\begin{array}{l}\text { Kalimantan } \\
\text { Agam, West Sumatera }\end{array}$ \\
\hline 96 & 20974 & Limar & West Java & 139 & 4139 & Kuku Balam & Agam, West Sumatera \\
\hline 97 & 20977 & Sasak Jalan & East Kalimantan & 140 & & Sirandah & \\
\hline 98 & 20982 & Popot & East Kalimantan & 140 & 4141 & Tjogok & Solok, West Sumatera \\
\hline & & Kembang & & 141 & 4153 & Empat & Solok, West Sumatera \\
\hline 99 & 21073 & Singkan & East Kalımantan & 142 & 4176 & Padi Rasi & Aceh \\
\hline 100 & 21074 & Ketan Siam & East Kalimantan & 143 & 4224 & Djula Djuli A & Banyuwangi, East Java \\
\hline 101 & 21096 & Uyun & Jambi & 144 & 4225 & Hoing & Banyuwangi, East Java \\
\hline 102 & 21116 & Kwatik Tinggi & Jambi & 145 & 4227 & Makmur & Banyuwangi, East Java \\
\hline 103 & 21119 & Rumbai ayam & Jambi & 146 & 4231 & Revolusi & Banyuwangi, East Java \\
\hline & & Padi Rantau & & 147 & 4240 & Gropak Serung & Lumajang, East Java \\
\hline 104 & 21120 & Undik & Bengkulu & 148 & 4242 & Itun & Lumajang, East Java \\
\hline 105 & 21123 & Cinta Kasih & Bengkulu & 149 & 4257 & Nangka Bosok & Malang, East Java \\
\hline 106 & 21124 & Padi Bugis & Bengkulu & 150 & 4260 & Bengawan & Malang, East Java \\
\hline 107 & 21126 & Surya & Bengkulu & 151 & 4268 & Sijem & Malang, East Java \\
\hline 108 & 21181 & Beras merah & West Java & & & & Kota Waringin, Central \\
\hline 109 & 21183 & Slereng & West Java & 152 & 4285 & Sampa Kirıng & Kalimantan \\
\hline 110 & 6329A & Pae Laguh & South East Sulawesi & 153 & 12287 & Pelopor & Semarang, Central Java \\
\hline 111 & 10065 & Ketan Jambruk & Bantul, Yogyakarta & 154 & 12293 & Cempo Slamet & Semarang, Central Java \\
\hline 112 & 10077 & Sate Liko & Bantul, Yogyakarta & 155 & 12302 & Ketan Uis & Bandung, West Java \\
\hline 113 & 10221 & Pulu Bolong & Bone, South Sulawesi & 156 & 12303 & Loyang & Bandung, West Java \\
\hline & & & Kolaka, North & 157 & 12353 & Jerah & Cianjur, West java \\
\hline 114 & $104 / 9$ & Pare Solo & Sulawesi & 158 & 12354 & Ketan Wangi & Tangerang, Banten \\
\hline 115 & 10578 & Pulut Tomene & South East Sulawesi & 159 & 12366 & Marus & Cianjur, West java \\
\hline 116 & 15016 & Horeg & Cirebon, West java & 160 & 12372 & Koneng Gundil & Cianjur, West java \\
\hline 117 & 11720 & Majair & $\begin{array}{l}\text { Lampung, North } \\
\text { Lampung }\end{array}$ & 161 & 12563 & Sirandah Lunto & $\begin{array}{l}\text { Tanah datar, West } \\
\text { Sumatera }\end{array}$ \\
\hline 118 & 11731 & Kalimic & Lampung, North & 162 & 19625 & Cisadane & Bogor, West Java \\
\hline 118 & $11 / 31$ & Kalımis & Lampung & 163 & 19629 & Semeru & Bogor, West Java \\
\hline & & & Lampung, Central & 164 & $\mathrm{C} 1$ & IRBB7 & IRRI \\
\hline 119 & 11920 & Termas & Lampung & 165 & $\mathrm{C} 2$ & IR24 & IRRI \\
\hline & 12074 & DR (Daya Itoh & & 166 & $\mathrm{C} 3$ & Conde & ICABIOGRAD \\
\hline 120 & $120 / 4$ & & Lampung & 167 & $\mathrm{C} 4$ & Kencana Bali & ICABIOGRAD \\
\hline
\end{tabular}

North Sumatera

Deli Serdang, North

Sumatera

Bogor, West Java

Amplification reactions were carried out in Tanjung Jabung, Jambi genomic DNA, 1.0 $\mu \mathrm{M}$ each of primer, 12.5 Semarang, Central Java $\mu \mathrm{M}$ each of dATP, dCTP, dGTP and dTTP, 1 Semarang, Central Java unit of Taq DNA Polymerase, 1X Taq Semarang, Central Java polymerase buffer and $2.5 \mathrm{mM} \mathrm{MgCl2}$. DNA Bateng, Central java amplification was performed in a Tetrad MJ Garut West Java Research Thermal Cycler programmed as follows: an initial denaturation of $4 \mathrm{~min}$ at 
$94^{\circ} \mathrm{C} ; 35$ cycles of $94^{\circ} \mathrm{C}$ for $1 \mathrm{~min}$ (denaturation), $50 / 55^{\circ} \mathrm{C}$ for $1 \mathrm{~min}$ (depending on optimal annealing temperature of each primer), and $72^{\circ} \mathrm{C}$ for $1 \mathrm{~min}$ (extension). One additional cycle of $10 \mathrm{~min}$ at $72^{\circ} \mathrm{C}$ was used for final extension. Amplified products were separated by electrophoresis in either $3 \%$ agarose gels run in $0.5 \mathrm{X}$ TBE or $8 \%$ polyacrylamide gel at $100 \mathrm{~V}$ (Dual TripleWide Mini-Vertical System, C.B.S. Scientific, CA, USA), visualized under UV light following addition of ethidium bromide using a gel documentation system (BioRad).

Table 2. List of BLB isolates/pathotypes used in this study

\begin{tabular}{llllc}
\hline No. & Isolates & Host & Province & Pathotype \\
\hline 1 & Xoo1110 & Ciherang & $\begin{array}{l}\text { Cianjur, } \\
\text { West Java }\end{array}$ & VI \\
2 & Xoo1122 & $\begin{array}{l}\text { Kuriak } \\
\text { Putiah }\end{array}$ & $\begin{array}{l}\text { Maninjau, } \\
\text { West } \\
\text { Sumatera }\end{array}$ & V \\
& & Maninjau, & XII \\
3 & Xoo1130 & $\begin{array}{l}\text { Kuriak } \\
\text { Putiah }\end{array}$ & $\begin{array}{l}\text { West } \\
\text { Sumatera }\end{array}$ & \\
\hline
\end{tabular}

Table 3. List of SSR primers used in this study.

\begin{tabular}{|c|c|c|c|c|}
\hline No. & Primer & Sequence & $\begin{array}{l}\text { Repeat } \\
\text { Motif }\end{array}$ & $\begin{array}{l}\text { size } \\
\text { (bp) }\end{array}$ \\
\hline 1 & RM20573 & $\begin{array}{l}\text { F:ggctattcctttcctcctctcc } \\
\text { R:aatcttcacgtgtgcgaactagc }\end{array}$ & (CT) 10 & 197 \\
\hline 2 & RM20580 & $\begin{array}{l}\text { F:cgtcacttcaccagcctgtagec } \\
\text { R:gtccatcatgcccatccatcc }\end{array}$ & (CT) 10 & 99 \\
\hline 3 & RM20582 & $\begin{array}{l}\text { F:agagcgtcgtcttcaccatcc } \\
\text { R:ggccaatacgacgatacattacacg }\end{array}$ & (TCT) 7 & 83 \\
\hline 4 & RM20589 & $\begin{array}{l}\text { F:catgtatttgtgtgcacgtaccg } \\
\text { R:accttcttgggcctttcttgg }\end{array}$ & (AC) 22 & 263 \\
\hline 5 & RM20590 & $\begin{array}{l}\text { F:ttcgatgagcactttccttgtcc } \\
\text { R:gcctcgecgattcacttatgc }\end{array}$ & (AT) 28 & 343 \\
\hline 6 & RM20591 & $\begin{array}{l}\text { F:tcgtctgcgcgaatatttagagagg } \\
\text { R:atctgcatcggagtcagcaacg }\end{array}$ & (TGGA)6 & 195 \\
\hline 7 & RM20593 & $\begin{array}{l}\text { F:aaggtacacttgctctgacggtagc } \\
\text { R:agacctcagtggcaaatcctacg }\end{array}$ & (CT) 12 & 315 \\
\hline 8 & RM20595 & $\begin{array}{l}\text { F:aacttcctttccaggctttcagc } \\
\text { R:ttcactgagcetgaacacattgc }\end{array}$ & (TA) 10 & 169 \\
\hline 9 & RM20601 & $\begin{array}{l}\text { F:ggagtgaaactgaggctcctatcg } \\
\text { R:tcgttctccttgcaagttatgg }\end{array}$ & (TA) 13 & 406 \\
\hline 10 & RM20603 & $\begin{array}{l}\text { F:tacaaatcaacagccaccacagc } \\
\text { R:ccatttggaacagattggacttgg }\end{array}$ & $(\mathrm{CAA}) 8$ & 101 \\
\hline 11 & RM20608 & $\begin{array}{l}\text { F:ttcgatcagtcagatagtcacg } \\
\text { R:tcttgcttcagtctgctacacc }\end{array}$ & (GA) 17 & 145 \\
\hline 12 & RM20612 & $\begin{array}{l}\text { F:tgtctctcgatacctcccatacc } \\
\text { R. } g c c c a c t c t c t \text { totcctatcc }\end{array}$ & (AG) 13 & 152 \\
\hline
\end{tabular}

\section{Data Analysis.}

The disease extent of rice germplasms was assessed and grouped based on their resistance using statistical analysis software program NTSYSpc 2.11p (Rohlf, 2005). Resistance or susceptibility was coded in a binary form of 1 or 0 , respectively. The Dice Coefficient (SIMQUAL) and UPGMA method (Unweighted Pair Group Method Arithmetic) were used to cluster the varieties and visualize their genetic relatedness to each other.

The bands of $X a 7$ allele were noted from the polymorphic band patterns of the PCR products. The bands of $\mathrm{Xa} 7$ allele were standardized using the amplified PCR products of IRBB7 and IR24 used as control. SSR analysis was conducted based on their allele size. The genetic distance was calculated using $D c$ implemented by Cavalli and Edwards (1967) in PowerMarker V3.23 (Liu and Muse, 2004). The germplasms were grouped based on their SSR profile using statistical analysis software program NTSYSpc 2.11p (Rohlf, 2005). The Dice Coefficient and UPGMA method used to cluster the varieties and visualize their genetic relatedness to each other. Tassel v.3.0 (Bradbury et al., 2007) was used to determine the association testing between SSR markers and BLB resistance. The P-value determined whether a QTL is associated with the marker and the $\mathrm{R}^{2}$-marker evaluated the magnitude of the QTL effects.

\section{Results \\ Disease Assessment of Rice Germplasms.}

BLB is a vascular disease that spreads through the xylem vessels. Lesions usually begin at the margin, a few centimeters from the tip, as water-soaked stripes. It can occur at any stages of the rice plants' growth. At the seedling stage, the symptoms first appeared as tiny water-soaked spots at the margin of the rice leaf blade. Then, it will enlarge and the rice plants turn yellow and wither. The symptoms of the disease at the seedling stage is known in local language (Bahasa Indonesia) as kresek.

The plants' reactions to pathogen infection varied. Symptoms such as pale green or grayish green patches on the leaves indicated infected germplasms. In the spots, oozing milky-white bacteria could be seen on the surface of the leaves in the morning. In resistant cultivars IRBB7 and Conde (Figure 1: leaf no. A1, A2, B1, B2, C1 and $\mathrm{C} 2$ ) and resistant germplasms (Figure 1: leaf no. 5, 6, 7, 8 ), the spots developed into a yellowish-white color on leaves with a wavy tip. On the other hand, in the susceptible cultivars Kencana Bali 
and IR24 (Figure 1: leaf no. A3, A4, B3, B4, $\mathrm{C} 3$ and $\mathrm{C} 4)$ lesions were observed in all parts of the infected leaves, accompanied by a color change to slightly white or grey, and the leaves became dry and died.

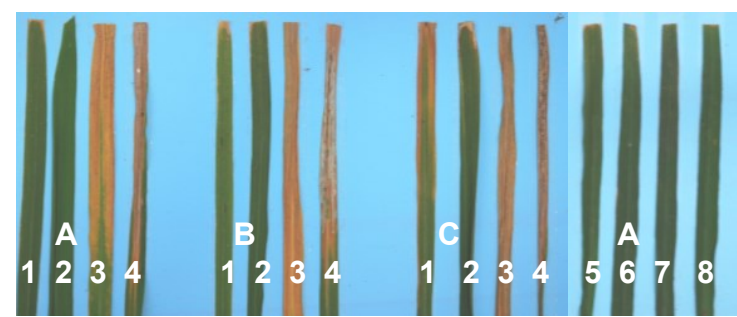

Figure 1. Lesions on leaves detected 14 days after inoculation with (A) Xoo1110, (B) Xoo1122, (C) Xoo1130. From left to right: Leaf no 1) IRBB7, 2) Conde, 3) Kencana Bali and 4) IR24, (5) Payak Tembakau (6) Padi Bugis, (7) Surya, and (8) Pare Puluglia.

The BLB intensity in resistant varieties (IRBB7 and Conde having the $\mathrm{Xa} 7$ resistance gene) against Xoo1110 (Pathotype VI) and Xoo1122 (Pathotype V) when measured as lesion size were less than $5 \%$, whereas for the Xoo1130 (Pathotype XII), it was higher than $10 \%$. It suggested that Xoo1130 was more virulent than the other two isolates/pathotypes and could overcome the $X a 7$ resistance gene in IRBB7 and Conde varieties. The BLB intensity in susceptible varieties, IR24 and Kencana Bali, were higher than $30 \%$ in terms of lesion size against the three BLB isolates/pathotypes tested. These two isolates showed a moderate susceptibility against the three BLB isolates/pathotypes tested (Figure 2).

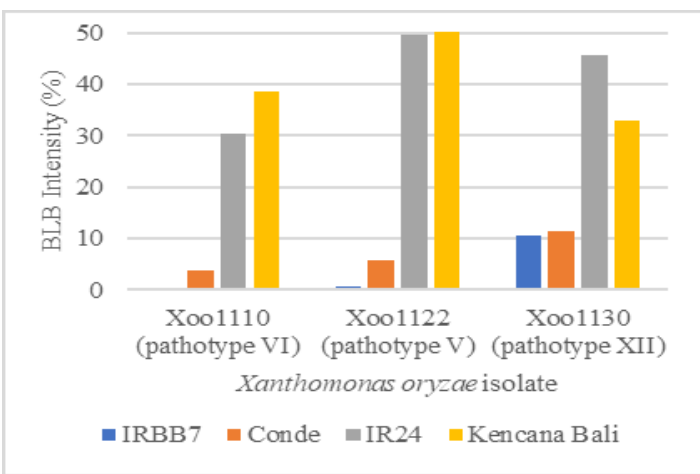

Figure 2. The BLB intensity of resistant controls (IRBB7 and Conde) and susceptible controls (IR24 and Kencana Bali) against the three isolates/pathotypes tested.
The BLB scores on 167 indigenous rice germplasms revealed that more than $68 \%$ rice accessions displayed a medium susceptibility (score 5) to high susceptibility (score 8) against the three BLB isolates/pathotypes tested (Suppl. 1). There were $54(32.3 \%)$ rice accessions found to be resistant to Xoo 1110 (Pathotype VI), 41 (24.5\%) were resistant to Xoo1122 (pathotype V), and $22(13.2 \%)$ were resistant to Xoo1130 (pathotype XII) (Figure 3). Payak Tembakau, Pare Pulunglia, Sate Liko, Pulu Bolong, Horeg, and Sijem cultivars were resistant to all three isolates/pathotypes tested (Table 4).

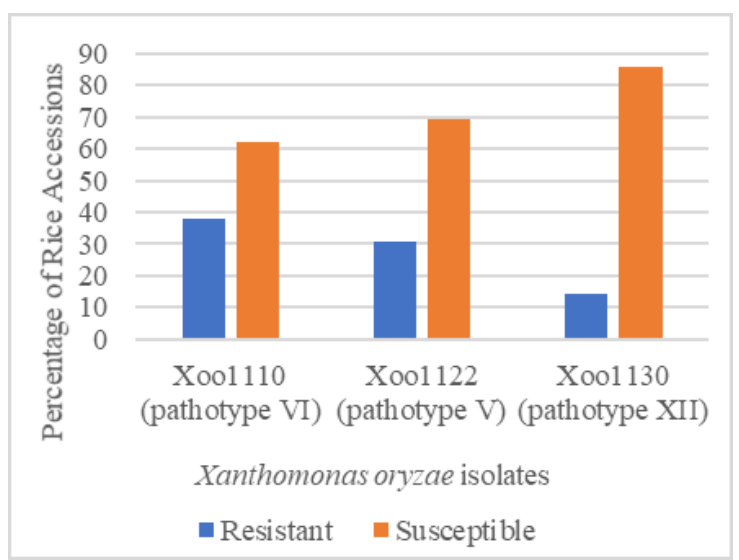

Figure 3. The percentages of resistant and susceptible Indonesian rice germplasms to the three isolates/pathotypes tested.

Table 4. The resistance profiles of Indonesian rice germplasms against the three isolates/pathotypes tested.

\begin{tabular}{|c|c|c|}
\hline $\begin{array}{l}\text { No. of } \\
\text { resistance } \\
\text { occurrence }\end{array}$ & $\begin{array}{c}\text { Xoo } \\
\text { Isolates } \\
\text { /pathotypes }\end{array}$ & Resistant Accessions \\
\hline 1 & $\begin{array}{l}\text { Xoo1110 } \\
\text { /pathotype } \\
\text { VI }\end{array}$ & $\begin{array}{l}\text { Biduin, Abang, Terotel, } \\
\text { Wuri Bura, Secangkir, } \\
\text { Jhapara, Tuma, Seratus } \\
\text { Malam, Dular, Sibentar, } \\
\text { Siremut, Buhbolon, } \\
\text { Danau Atas, Poso, } \\
\text { Baung, Banjar Sawan, } \\
\text { Kail, Bonti, Putri } \\
\text { Manis, Keakubi, Ketan } \\
\text { Jambruk, Pare Solo, } \\
\text { Pulut Tomene, Sri } \\
\text { Makmur, Empat, } \\
\text { Hoing, Makmur, } \\
\text { Revolusi, Gropak } \\
\text { Sarung, Nangka Bosok, } \\
\text { Sampa Kiring, Pelopor, } \\
\text { Cempo Slamet, Jerah, } \\
\text { SiRandah Lunto, } \\
\text { Semeru. }\end{array}$ \\
\hline
\end{tabular}




\begin{tabular}{|c|c|c|}
\hline & $\begin{array}{l}\text { Xoo1122 } \\
\text { /pathotype V }\end{array}$ & $\begin{array}{l}\text { Putih Ampat Angkek, } \\
\text { Aluh Kuranji, Untup, } \\
\text { Mayor, Randah Pala, } \\
\text { Lalantik Bamban, Siam } \\
\text { Parapuk, Sara Kasa, } \\
\text { Pimpin, Si Pulo } \\
\text { Angkola, Kuala Deli, } \\
\text { Wajo Kuning, Ardas, } \\
\text { Ndangan Cantik 1, } \\
\text { Lokal Buntu Sangala 2, } \\
\text { Cere Gelas, Uyun, } \\
\text { Kwatik Tinggi, Padi } \\
\text { Rantau Undik, Cempo. }\end{array}$ \\
\hline & $\begin{array}{l}\text { Xoo1130 } \\
\text { /pathotype } \\
\text { XII }\end{array}$ & $\begin{array}{l}\text { Idi, Si Motung, } \\
\text { Angkong, Kembang } \\
\text { Ading, Kembang } \\
\text { Singkan, Pae Laguh, } \\
\text { Kalimis. }\end{array}$ \\
\hline \multirow{3}{*}{2} & $\begin{array}{l}\text { Xoo1110+ } \\
\text { Xoo1122 }\end{array}$ & $\begin{array}{l}\text { Brown Gora, Lemo, Si } \\
\text { Pulo Mandailing, Cinta } \\
\text { Kasih, Majair, Nolo } \\
\text { Kario, Lumbu, Sera }\end{array}$ \\
\hline & $\begin{array}{l}\text { Xoo1110+ } \\
\text { Xoo1130 }\end{array}$ & SiRuguek, Cisadane \\
\hline & $\begin{array}{l}\text { Xoo1122+ } \\
\text { Xoo1130 }\end{array}$ & $\begin{array}{l}\text { Goter, Surya, Daya Itoh } \\
\text { Rice 4, Padi Bugis, Si } \\
\text { Gudang }\end{array}$ \\
\hline 3 & $\begin{array}{l}\text { Xoo1110+ } \\
\text { Xoo1122+ } \\
\text { Xoo1130 }\end{array}$ & $\begin{array}{l}\text { Payak Tembakau, Pare } \\
\text { Pulunglia, Sate Liko, } \\
\text { Pulu Bolong, Horeg, } \\
\text { Sijem }\end{array}$ \\
\hline
\end{tabular}

Cluster analysis calculated from BLB scoring (resistant: score 1-4 and susceptible: score 5-9) was constructed. A cutoff value of 0.65 was used for genetic similarity among all varieties as the threshold for UPGMA clustering, which resulted in four major groups. Group 1 represented accessions displaying resistance to all three BLB isolates/pathotypes. This group included the IRBB7 and Conde varieties and consisted of 10 accessions (6\%): Horeg, Pare Pulunglia, Sijem, Sate Liko, Pulu Bolong, Payak Tembakau, Padi Bugis, Goter, Surya, and Daya Itoh Rice 4. Group 2 represented accessions resistant to only one BLB isolate/pathotype (Xoo1130), Group 3 represented accessions susceptible to all three BLB isolates/pathotypes, and Group 4 represented accessions resistant to one or two BLB isolates/pathotypes (Suppl.2).

\section{Molecular Marker Analysis.}

Eight out of twelve SSRs used for genotyping showed good polymorphism and were able to be measured in 56 Indonesian rice germplasms (Figure 4). Polymorphic analysis revealed the genetic variations that exist, namely 31 alleles with an average of four alleles per locus - the range was two (RM20595 and RM20603) to six alleles (RM20590). Polymorphism Information Content (PIC) values averaged at 0.34 and ranged from a low of 0.06 (RM20573) to a high of 0.53 (RM20582). RM20573 showed the highest frequency allele, whereas RM20612 showed the lowest frequency allele (Table 5). The presence of 31 alleles in the 56 accessions indicated a low genetic diversity within the BLB $X a 7$ resistance gene locus and a low PIC value.

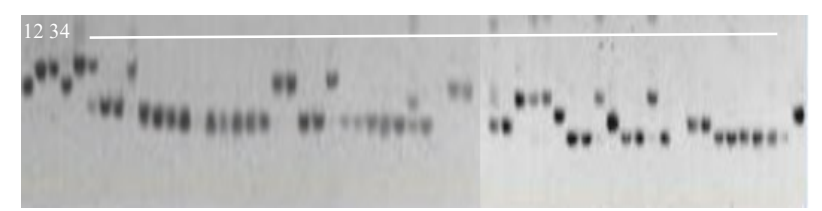

Figure 4. Polymorphic analysis of Indonesian rice germplasms using SSR marker RM20582. Lane 1: IRBB7, lane 2: IR64, lane 3: IR24, lane 4-53 Indonesian rice germplasms.

Table 5. Statistical summary of molecular marker analysis of 56 rice accessions

\begin{tabular}{lcccc}
\hline Marker & $\begin{array}{c}\text { Size } \\
\text { Range } \\
\text { (bp) }\end{array}$ & $\begin{array}{c}\text { Allele } \\
\text { Number }\end{array}$ & $\begin{array}{c}\text { Allele } \\
\text { Frequency }\end{array}$ & PIC \\
\hline RM20573 & $197-310$ & 3 & 0.9649 & 0.0672 \\
RM20582 & $80-83$ & 4 & 0.5614 & 0.5320 \\
RM20589 & $235-600$ & 5 & 0.7895 & 0.3393 \\
RM20590 & $280-400$ & 6 & 0.7895 & 0.3545 \\
RM20591 & $190-195$ & 4 & 0.5965 & 0.4972 \\
RM20595 & $50-169$ & 2 & 0.8246 & 0.2475 \\
RM20603 & $101-105$ & 2 & 0.8772 & 0.1922 \\
RM20612 & $152-160$ & 5 & 0.4561 & 0.5118 \\
\hline Average & & 4 & 0.7324 & 0.3427 \\
\hline
\end{tabular}

Cluster analysis was performed on similarity coefficient matrices calculated from the molecular markers to generate a dendrogram. When a cutoff value of 0.48 was used for genetic similarity among all varieties as the threshold for UPGMA clustering, two major groups were observed. Group 1 represented susceptible rice varieties consisting of 44 accessions and included the IR24 variety. Group 2 represented the resistant varieties, which included the IRBB7 and Conde varieties, and consisted of Sate Liko, Pulu Bolong, Horeg, Sijem, Majair, Daya Itoh Rice 4, Lumbu, Nolokario, Si Gudang and Cempo varieties (Suppl. 3). The dendrogram 
suggested that there was no geographical segregation of the rice accessions based on the obtained data.

Disease assessment of 167 rice germplasms against three BLB isolates/pathotypes analyzed using BLB scoring (Table 4), UPGMA cluster analysis (Suppl. 2), and molecular marker analysis (Suppl. 3) revealed that three germplasms displayed a consistent resistance profile: Sate Liko, Horeg and Sijem. A summary of results for those germplasms can be seen in Figure 5.

\begin{tabular}{|c|c|c|c|c|c|c|c|c|}
\hline SSRs & $\begin{array}{l}\stackrel{N}{\infty} \\
\stackrel{\infty}{\sim} \\
\stackrel{N}{\infty}\end{array}$ & 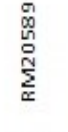 & 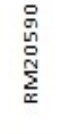 & 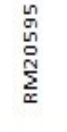 & $\begin{array}{l}\stackrel{m}{0} \\
\stackrel{D}{\mathscr{N}} \\
\sum_{\propto}\end{array}$ & & & \\
\hline$c M$ & 106,1 & 106,3 & 106,4 & 106,6 & 106,9 & & & \\
\hline BAC Clone & $\mathrm{B} 1472 \mathrm{FO2}$ & \multicolumn{2}{|c|}{ P0778G11 } & \multicolumn{2}{|c|}{ B1153E06 } & & & \\
\hline Function & $\begin{array}{l}\text { Serine/ } \\
\text { Arginine }\end{array}$ & \multicolumn{2}{|c|}{$\begin{array}{l}\mathrm{BTB} / \mathrm{POZ} \\
\text { domain }\end{array}$} & \multicolumn{2}{|c|}{$\begin{array}{l}\text { Glycosyl } \\
\text { hydrolase }\end{array}$} & & & \\
\hline Accession/ & & & & & & $X_{00}$ & $X_{00}$ & $X_{00}$ \\
\hline$X_{00}$ & & & & & & 1110 & 1122 & 1130 \\
\hline Sate Liko & 80 & 235 & 280 & 50 & 105 & $R$ & $R$ & $R$ \\
\hline Horeg & 80 & 500 & 400 & 50 & 101 & $R$ & MR & $R$ \\
\hline Sijem & 70 & 235 & 280 & 169 & 105 & MR & MR & $R$ \\
\hline IRBB7 & 80 & 600 & 343 & 50 & 101 & $R$ & $R$ & $R$ \\
\hline IR24 & 80 & 500 & 280 & 169 & 105 & MS & MS & MS \\
\hline
\end{tabular}

Figure 5. Genotyping of the region containing $X a 7$ gene for each rice accession displaying consistent resistance profiles. SSRs $=$ simple sequence repeats, $\mathrm{R}=$ resistant, $\mathrm{MR}=$ Medium Resistance and $\mathrm{MS}=$ Medium Susceptible. Centimorgan (cM) refers to relative distances along the Nipponbare BAC.

\section{Association Analysis.}

Association analysis performed using a General linear model has identified markertrait associations $(\mathrm{P}<0.05)$ of BLB resistance (Xoo1130/pathotype XII). Evaluation of six out of eight markers revealed a significant association between BLB resistance and markers (Table 6).

Table 6. Association $\left(\mathrm{R}^{2}\right)$ of SSR markers with resistance to BLB

\begin{tabular}{lllll}
\hline \multirow{4}{*}{ Trait } & $\begin{array}{l}\text { SSR } \\
\text { Marker }^{\mathrm{a}}\end{array}$ & $\begin{array}{l}\text { Position } \\
(\mathrm{Mb})\end{array}$ & $\mathrm{P}$ & $\mathrm{R}^{2 \mathrm{~b}}$ \\
\hline BLB & RM20582 & 27.91 & 0.0141 & 0.2708 \\
Resistant & RM20589 & 27.93 & 0.0004 & 0.4820 \\
& RM20590 & 28.01 & 0.0000 & 0.6211 \\
& RM20595 & 28.08 & 0.0097 & 0.2093 \\
& RM20603 & 28.15 & 0.0029 & 0.2668 \\
& RM20612 & 28.29 & 0.0065 & 0.4113 \\
\hline
\end{tabular}

${ }^{a}$ Only SSR markers with a significant marker-trait association are reported

${ }^{\mathrm{b}} \mathrm{R}^{2}$ indicates the percentage of the total variation explained

\section{Discussion}

Natural selection has generated landraces with highly diverse quality, quantity and disease resistance traits-controlling loci. It is important to identify and maintain polymorphisms to broaden the genetic base of commercially cultivated varieties and to reduce pathogen pressure (Das et al., 2014). Assessing diversity from large germplasm collections pose significant challenges, therefore this study concentrated on a small group of representative accessions before extending to a broader range of varieties.

Previous studies mentioned that $x a 5, X a 21$, and $X a 7$ resistance genes are effective against the majority of the Xoo isolates/pathotypes in Indonesia. (Fatimah et al., 2014; Tasliah et al., 2013; Hifni and Kardin, 1998). Hifni and Kardin (1998) reported that based on IRRI differential varieties, the population of Xoo isolates of pathotypes $\mathrm{V}$ and VI are the dominant pathotypes in Indonesia. Pathotype $\mathrm{V}$ could not overcome rice varieties with $x a 5$, $X a 7$, and $X a 21$ resistance genes, whereas pathotype VI could not overcome rice varieties with $x a 5$ and $X a 7$ resistance genes. Pathotype XII was found to be the most virulent Xoo isolate and could overcome the rice varieties with more than ten resistance genes, but fortunately the population of Xoo isolates with pathotype XII is relatively low (Hifni and Kardin, 1998). However, in recent years pathotype XII was the most dominant pathotype found in 15 out of 22 districts in Central Java Province (Yuliani et al., 2018) and several rice growing areas in South Sulawesi showed a shift to a larger proportion of pathotype XII (Asysyuura et al., 2017).

Looking at 165 rice accessions and two resistant control varieties having $\mathrm{Xa} 7$ resistance gene (IRBB7 and Conde varieties), the results of this study found that Xoo1130 (pathotype XII) was the most virulent compared to Xoo1110 (Pathotype VI) and Xoo1122 (pathotype V) (Figure 3). Implications of this study are that potentially, pathotypes V and VI could be used for selection of breeding lines with three resistance genes ( $x a 5, \mathrm{Xa} 7$ and $\mathrm{Xa21}$ ), while pathotype XII could be used to evaluate rice germplasm collection as a new source of resistance gene against Xoo.

The disease assessment of Indonesian rice germplasms by screening with three BLB 
isolates/pathotypes and genotyping using SSR primer linked to $\mathrm{Xa} 7$ resistance gene revealed three out of 167 accessions that displayed a consistent resistant profile, i.e: Sate Liko, Horeg, and Sijem. It indicated that these three rice germplasms with a high degree of resistance could be a new source of resistance gene against BLB disease and can potentially be used to diversify the genetic base of core breeding sets.

Analyzing the phenotype-genotype association after an actual disease inoculation is a prerequisite for confirming BLB resistance with allele identification. Fine mapping of $\mathrm{Xa} 7$ resistance gene has been previously constructed (Chen et al., 2008; Zhang et al., 2009). The $X a 7$ gene is located in an approximately $200-\mathrm{kb}$ segment in the subtelomeric region of chromosome 6 (Zhang et al., 2009). Several candidate genes that have been identified include $\mathrm{BTB} / \mathrm{POZ}$ and Nramp6, known to be involved in plant resistance (Chen et al., 2008). Those genes are located within the $84 \mathrm{~kb}$ region comprising the SNPs detected in GWAS (Dilla-Ermita et al., 2017).

In this study, among the six markers evaluated in Indonesian rice germplasms, two markers (RM20589 and RM20590) revealed a high association with isolate Xoo1130 (pathotype XII) (Table 6), indicating that RM20589 and RM20590 were the closest markers to the $\mathrm{Xa} 7$ resistance gene. These primers were located on BAC clone P0778G11 of Loc_Os06g46240 in region 28,007,285$28,017,490 \mathrm{bp}(10.2 \mathrm{~kb})$ on rice plant genome. This region is known as the $\mathrm{BTB} / \mathrm{POZ}$ domain-containing protein, putative, expressed (MSU Rice Genome Annotation Project). These results are similar to an earlier study (Fatimah et al. 2018) that screened $\mathrm{BC}_{1: 2} \mathrm{~F}_{2}$ individuals with 35 primers and revealed the significance of primer Xa7LD37 with $\mathrm{Xa} 7$ resistance gene. This primer was located between primer RM20589 and RM20590.

These results demonstrated the application of SSR primers in elucidating resistance to BLB in Indonesian rice germplasms that would enable discovery of significant SSR markers for marker-assisted selection. Efficient tracking of $\mathrm{Xa} 7$ genes in the breeding pipeline provides breeders an insight that it is feasible to combine multiple genes (gene pyramiding) having complementary resistance spectra into a single plant genotype. This approach can provide a broad-spectrum of resistance that ensures maintenance of durability of $\mathrm{Xa}$ genes deployed in the field. The feasibility of this approach was demonstrated by Fatimah et al. (2015) where gene pyramiding on three BLB resistant genes $x a 5, X a 7$ and Xa21 from Angke, Conde, and IRBB21 varieties into Ciherang and Inpari 13 elite varieties were performed and combined in a single BLB resistant gene $\mathrm{Xa} 4$ background.

In conclusion, the majority of the indigenous Indonesian rice germplasms were susceptible to the three BLB isolates/pathotypes tested. Sate Liko from Bantul, Yogyakarta, Horeg from Cirebon, West Java and Sijem from Malang, East Java showed consistent resistance based on BLB evaluation in greenhouse using three isolates/pathotypes tested, UPGMA analysis, and genotyping using SSR markers linked to $X a 7$ resistance gene. For future studies, these indigenous rice germplasms are potential donors that can confer resistance to multiple pathotypes and therefore are useful to be used in breeding and improvement program for BLB resistant-varieties in Indonesia.

\section{Acknowledgements}

This work was financially supported by the $16^{\text {th }}$ Indonesian Toray Science Foundation grant.

\section{References}

Adhikari, T.B., Cruz, C.M.W., Zhang, Q, Nelson, R.J., Skinner, D.Z., Mew, T.W., \& Leach, J.E. (1995) Genetic diversity of Xanthomonas oryzae pv. oryzae in Asia. Applied and Environmental Microbiology, 61:966-971.

Asysyuura, Nawangsih, A.A., Mutaqin, K.H., Sudir. (2017). Identifikasi patotipe Xanthomonas oryzae pv. oryzae dari tanaman padi di Sulawesi Selatan. Jurnal Fitopatologi Indonesia, 13(3): 73-80. http://doi.org/cmk7.

Bradbury, P.J. et al. (2007). TASSEL: software for association mapping of complex traits in diverse samples. Bioinformatics 23:2633-2635.

Cavalli-Sforza and Edwards. (1967). Phylogenetic analysis. Models and estimation procedures. The American Journal of Human Genetics, 19(3):233-257.

Chaudry, R.C. (1996). Standard evaluation system for rice. Genetic Res. $4^{\text {th }}$ Edition, Cent. Intl. Rice Res. Instit. Manila, Philippines. pp. 52. 
Chen, S., Huang, Z., Zeng, L., Yang, J., Liu, Q., \& Zhu, X. (2008). High-resolution mapping and gene prediction of Xanthomonas oryzae pv. oryzae resistance gene Xa7. Molecular Breeding 22:433-441.

Cruz, V. C.M., Bai, J., Ona, L., Leung, H., Nelson, R.J., Mew, T.W., \& Leach J.E. (2000). Predicting durability of a disease resistance gene based on an assessment of the fitness loss and epidemiological consequences of avirulence gene mutation. Proceedings of the National Academy of Sciences, 97:1350013505.

Das, B., Sengupta, S., Prasad, M., \& Ghose, T. K. (2014). Genetic diversity of the conserved motifs of six bacterial leaf blight resistance genes in a set of rice landraces. $B M C$ Genet 15, 82. https://doi.org/10.1186/14712156-15-82.

Dellaporta, S.L., Wood, J., \& Hicks, J.B. (1983). A plant DNA minipreparation: version II. Plant Molecular Biology Reporter, 1: 19-21.

Dilla-Ermita, C.J., Tandayu, E., Juanillas, V.M., Detras, J., Lozada, D.N., Dwiyanti, M.S., Cruz, C.V., Mbanjo, E.G.N., Ardales, E., Diaz, M.G., Mendioro, M., Thomson, M.J., \& Kretzschmar, T. (2017). Genome-wide association analysis tracks bacterial leaf blight resistance loci in rice diverse germplasm. Rice, $10(8): 1-17$. DOI 10.1186/s12284-017-0147-4.

Fatimah, Priyatno, T.P., Fadlillah, S.H., Hermanto, Baroya, M., Mahrup, Wawan, Sasongko, D., Suryadi, Y., \& Kadir, T.S. (2014). Isolation and disease assessment of Xanthomonas oryzae pv. oryzae from Java Island and pathogenic assay on near isogenic lines with different resistant genes. Jurnal Biologi Indonesia, 10(2):243-252.

Fatimah, Prasetiyono, J., Priyatno, T.P., Yunus, M., Suhartini, T., Ridwan, I., Baroya, M. (2015). Analisis molekuler piramida gen $X a$ pada progeni padi Varietas Ciherang dan Inpari 13. Jurnal Biologi Indonesia, 11(1):109-119.

Fatimah, Prasetiyono, J , Polosoro, A. \& Baroya, M. (2018). Molecular detection of resistance to bacterial leaf blight on Indonesian rice conde variety. Annales Bogoriensis, 22(1):27-34.

Hifni, H.R. and Kardin, M.K. (1998). Pengelompokan isolat Xanthomonas oryzae pv. oryzae dengan menggunakan galur isogenik padi IRRI. Hayati Journal of Biosciensces, 5(3): 66-72.

Kauffman, H.E., Reddy, A.P.K., Hsieh, S.P.Y., Merca, S.D. (1973). An improved technique for evaluating resistance of rice varieties to Xanthomonas oryzae pv. oryzae. Plant Diseases. Rep, 57: 537-541.

Liu, K., \& Muse, S. (2004) PowerMarker: new genetic data analysis software. Version 3.0. http://www.powermarker.net.

Neelam, K., Mahajan, R., Gupta, V., Bhatia, D., Gill, B.K., Komal, R. Lore, J.S., Mangat, G.S., and Singh, K. ( 2020). High-resolution genetic mapping of a novel bacterial blight resistance gene $x a-45(\mathrm{t})$ identified from Oryza glaberrima and transferred to Oryza sativa. Theoretical Applied Genetics, 133(3):689-705. doi: 10.1007/s00122-019-03501-2.

Ogawa,T., Yamamoto, T. Kush, G.S., \& Mew, T.W. (1991). Breeding of near isogenic lines of rice with single gene for resistance to bacterial blight pathogen (Xanthomonas campestris pv. oryzae). Japanese Journal of Breeding, 41:523-529.

Rohlf, F. J. (2005). NTSYS-pc: numerical taxonomy and multivariate analysis system, version 2.2. Exeter Software: Setauket, NY.38p.Dc.

Sidhu, G.S., Kush, G.S.. \& Mew. T.W. (1978). Genetic analysis of bacterial leaf blight resistance in seventy-four cultivars of rice, Oryza sativa L. Theoretical Applied Genetics, 53:105-111.

Syam, M., \& Hermanto. (1995). Rice production technology: supporting sustainable rice selfsufficient in Indonesia. Central Research Institute for Food Crops. Agency for Agricultural Research and Development. Bogor. Indonesia. $62 p$.

Tasliah, Mahrup, \& Prasetiyono. J. (2013). Identifikasi molekuler hawar daun bakteri (Xanthomonas oryzae pv. oryzae) dan uji patogenisitasnya pada galur-galur padi isogenic. Jurnal Agrobiogen, 9(2):49-57.

Yuliani, D., Rohaeni, W.R. Sudir. (2018). Evaluasi ketahanan galur International Rice Bacterial Blight terhadap hawar daun bakteri dan identifikasi patotipe Xanthomonas oryzae pv. oryzae Provinsi Jawa Tengah berdasarkan Galur IRBB. Jurnal Ilmu Pertanian Indonesia, 23(1): 52-59. DOI: 10.18343/jipi.23.1.52

Zhang, Y., Wang, J., Pan, J., Gu, Z., Chen, X., Jin, Y., Liu, F., Zhang, H., \& Ma, B. (2009) Identification and molecular mapping of the rice bacterial blight resistance gene allelic to $X a 7$ from an elite restorer line Zhenhui 084. European Journal of Plant Pathology, 125(2):235-244. 


\section{Supplement}

Table 1. BLB Scoring of rice accession against BLB isolates used in this study.

\begin{tabular}{|c|c|c|c|c|c|c|c|c|c|c|c|c|c|c|c|}
\hline \multirow[t]{2}{*}{ No. } & \multirow{2}{*}{$\begin{array}{l}\text { Accession } \\
\text { Name }\end{array}$} & \multicolumn{2}{|c|}{$\begin{array}{l}\text { Xoo } \\
1110 \\
\end{array}$} & \multicolumn{2}{|c|}{$\begin{array}{l}\text { Xoo } \\
1122\end{array}$} & \multicolumn{2}{|c|}{$\begin{array}{l}\text { Xoo } \\
1130 \\
\end{array}$} & \multirow[t]{2}{*}{ No. } & \multirow{2}{*}{$\begin{array}{l}\text { Accession } \\
\text { Name }\end{array}$} & \multicolumn{2}{|c|}{$\begin{array}{c}\text { Xoo } \\
1110 \\
\end{array}$} & \multicolumn{2}{|c|}{$\begin{array}{l}\text { Xoo } \\
1122\end{array}$} & \multicolumn{2}{|c|}{$\begin{array}{l}\text { Xoo } \\
1130\end{array}$} \\
\hline & & $\mathrm{B}$ & Cat. & $\mathrm{B}$ & Cat & $\mathrm{B}$ & Cat. & & & $\mathrm{B}$ & Cat. & $\mathrm{B}$ & Cat & $\mathrm{B}$ & Cat. \\
\hline \multirow{3}{*}{1} & Putih & & & & & & & & Segon & & & & & & \\
\hline & Ampat & & & & & & & 36 & Borondol & 5 & MS & 5 & MS & 5 & MS \\
\hline & Angkek & 5 & MS & 4 & MR & 5 & MS & 37 & Mojang & 5 & MS & 5 & MS & 6 & $\mathrm{~S}$ \\
\hline 2 & Reli & 6 & $\mathrm{~S}$ & 5 & MS & 5 & MS & 38 & Rangkong & 5 & MS & 5 & MS & 5 & MS \\
\hline \multirow{2}{*}{3} & Seng & & & & & & & & Cere & & & & & & \\
\hline & Kumang & 5 & MS & 5 & MS & 5 & MS & \multirow[t]{2}{*}{39} & Mentik/ & & & & & & \\
\hline 4 & Mingkai & 6 & $\mathrm{~S}$ & 5 & MS & 5 & MS & & Toray & $\mathrm{S}$ & $\mathrm{S}$ & 5 & MS & 5 & MS \\
\hline 5 & Rijah & 6 & S & 5 & MS & 6 & $\mathrm{~S}$ & \multirow{2}{*}{40} & Hawara & & & & & & \\
\hline \multirow{2}{*}{6} & Aluh & & & & & & & & Batu & 5 & MS & 5 & MS & 5 & MS \\
\hline & Kuranji & 6 & $\mathrm{~S}$ & 4 & MR & 5 & MS & 41 & Muncang & 5 & MS & 6 & $\mathrm{~S}$ & 6 & $\mathrm{~S}$ \\
\hline 7 & Kuning & & & & & & & 42 & Gondok & 6 & $\mathrm{~S}$ & 5 & MS & 6 & S \\
\hline 1 & Biaro & 5 & MS & 5 & MS & 5 & MS & 43 & Laila & 5 & MS & 6 & $\mathrm{~S}$ & 6 & S \\
\hline 8 & Gondak & & & & & & & & Padi & & & & & & \\
\hline$\gamma$ & Kiah & 5 & MS & 5 & MS & 5 & MS & 44 & Belanak & & & & & & \\
\hline 9 & Si Rendah & & & & & & & & Kosambi & 5 & MS & 5 & MS & 6 & $\mathrm{~S}$ \\
\hline 9 & Cogok & 6 & $\mathrm{~S}$ & 5 & MS & 5 & MS & & Padi & & & & & & \\
\hline 10 & Tromas & 5 & MS & 5 & MS & 5 & MS & 45 & Jambai & 5 & MS & 5 & MS & 5 & MS \\
\hline 11 & Goter & 5 & MS & 4 & MR & 4 & MR & 46 & Terotel & 4 & MR & 6 & $\mathrm{~S}$ & 5 & MS \\
\hline 12 & Untup & 5 & MS & 4 & MR & 5 & MS & 47 & Wuri Bura & 4 & MR & 5 & MS & 5 & MS \\
\hline 13 & Mayor & 6 & $\mathrm{~S}$ & 4 & MR & 5 & MS & 48 & Samada & 5 & MS & 5 & MS & 5 & MS \\
\hline 14 & Baliman & & & & & & & 49 & Dendak & 5 & MS & 5 & MS & 5 & MS \\
\hline 14 & Putih & 5 & MS & 5 & MS & 5 & MS & 50 & Lumbuk & 5 & MS & 5 & MS & 5 & MS \\
\hline 15 & Biduin & 4 & MR & 5 & MS & 5 & MS & 51 & Secangkir & 3 & $\mathrm{R}$ & 5 & MS & 5 & MS \\
\hline & Randah & & & & & & & 52 & Jhapara & 2 & $\mathrm{R}$ & 5 & MS & 5 & MS \\
\hline 10 & Pala & 6 & $\mathrm{~S}$ & 4 & MR & 6 & $\mathrm{~S}$ & 53 & Tuma & 2 & $\mathrm{R}$ & 5 & MS & 5 & MS \\
\hline 17 & $\begin{array}{l}\text { Lalantik } \\
\text { Bamban }\end{array}$ & 5 & MS & 4 & MR & 5 & MS & 54 & $\begin{array}{l}\text { Seratus } \\
\text { Malam }\end{array}$ & 2 & $\mathrm{R}$ & 5 & MS & 5 & MS \\
\hline 18 & Raden & & & & & & & & Brown & & & & & & \\
\hline 18 & Pulatar & 5 & MS & 5 & MS & 5 & MS & 55 & Gora & 4 & MR & 4 & MR & 5 & MS \\
\hline & Siam & & & & & & & 56 & Dular & 4 & MR & 5 & MS & 5 & MS \\
\hline 19 & Parapuk & 6 & $\mathrm{~S}$ & 4 & MR & 5 & MS & 57 & Sibentar & 3 & $\mathrm{R}$ & 5 & MS & 5 & MS \\
\hline 20 & Sara Kasa & 5 & MS & 4 & MR & 5 & MS & 58 & Siremut & 4 & MR & 5 & MS & 5 & MS \\
\hline 21 & Pingkan & 5 & MS & 5 & MS & 5 & MS & 59 & Buhbolon & 3 & $\mathrm{R}$ & 5 & MS & 5 & MS \\
\hline 22 & Pimpin & 5 & MS & 4 & MR & 6 & $\mathrm{~S}$ & 60 & Danau Atas & 2 & $\mathrm{R}$ & 6 & $\mathrm{~S}$ & 5 & MS \\
\hline 23 & Bengkonga & & & & & & & 61 & Poso & 2 & $\mathrm{R}$ & 5 & MS & 5 & MS \\
\hline 23 & ng & 5 & MS & 5 & MS & 5 & MS & 62 & Engkoran & 5 & MS & 6 & $\mathrm{~S}$ & 6 & $\mathrm{~S}$ \\
\hline & Cicih & & & & & & & 63 & Baung & 2 & $\mathrm{R}$ & 5 & MS & 5 & MS \\
\hline 24 & Buleleng & 5 & MS & 5 & MS & 5 & MS & & Banjar & & & & & & \\
\hline 25 & Angkong & 5 & MS & 5 & MS & 4 & MR & 64 & Sawan & 4 & MR & 6 & $\mathrm{~S}$ & 6 & $\mathrm{~S}$ \\
\hline 26 & Padi Book & 5 & MS & 5 & MS & 5 & MS & 65 & Kail & 4 & MR & 5 & MS & 5 & MS \\
\hline 27 & $\begin{array}{l}\text { Longandob } \\
\mathrm{u}\end{array}$ & 5 & MS & 5 & MS & 5 & MS & 66 & $\begin{array}{l}\text { Payak } \\
\text { Tembakau }\end{array}$ & 3 & $\mathbf{R}$ & $\mathbf{R}$ & $\mathbf{R}$ & 4 & MR \\
\hline & Padi Ana- & & & & & & & 67 & Ribun & 5 & MS & 5 & MS & 5 & MS \\
\hline 28 & Ana & 5 & MS & 5 & MS & 5 & MS & 68 & Bonti & 4 & MR & 5 & MS & 5 & MS \\
\hline 29 & Anambar & 5 & MS & 5 & MS & 5 & MS & 69 & Idi & 5 & MS & 5 & MS & 4 & MR \\
\hline 30 & Wulu Mata & 5 & MS & 5 & MS & 5 & MS & 70 & Syair & 5 & MS & 5 & MS & 5 & MS \\
\hline & Ingsa & & & & & & & 71 & Rangkoh & 5 & MS & 5 & MS & 5 & MS \\
\hline 31 & Cendana & 5 & MS & 5 & MS & 5 & MS & 72 & Si Reguek & 4 & MR & 5 & MS & 4 & MR \\
\hline 32 & Ingsa & & & & & & & & Putih & & & & & & \\
\hline 32 & Bondol & 5 & MS & 5 & MS & 5 & MS & 73 & Panjah & 5 & MS & 5 & MS & 5 & MS \\
\hline 33 & Banja Ili & 5 & MS & 5 & MS & 5 & MS & 74 & Bho & 5 & MS & 5 & MS & 5 & MS \\
\hline 34 & Rejuno & 5 & MS & 5 & MS & 5 & MS & 75 & Lemo & 4 & MR & 4 & MR & 5 & MS \\
\hline 35 & Abang & 4 & MR & 5 & MS & 5 & MS & 76 & Si Motung & 5 & MS & 5 & MS & 4 & MR \\
\hline
\end{tabular}




\begin{tabular}{|c|c|c|c|c|c|c|c|c|c|c|c|c|c|c|c|}
\hline \multirow[t]{2}{*}{ No. } & \multirow{2}{*}{$\begin{array}{l}\text { Accession } \\
\text { Name }\end{array}$} & \multicolumn{2}{|c|}{$\begin{array}{l}\text { Xoo } \\
1110 \\
\end{array}$} & \multicolumn{2}{|c|}{$\begin{array}{l}\text { Xoo } \\
1122 \\
\end{array}$} & \multicolumn{2}{|c|}{$\begin{array}{l}\text { Xoo } \\
1130 \\
\end{array}$} & \multirow[t]{2}{*}{ No. } & \multirow{2}{*}{$\begin{array}{l}\text { Accession } \\
\text { Name }\end{array}$} & \multicolumn{2}{|c|}{$\begin{array}{c}\text { Xoo } \\
1110 \\
\end{array}$} & \multicolumn{2}{|c|}{$\begin{array}{l}\text { Xoo } \\
1122 \\
\end{array}$} & \multicolumn{2}{|c|}{$\begin{array}{c}\text { Xoo } \\
1130 \\
\end{array}$} \\
\hline & & $\mathrm{B}$ & Cat. & $\mathrm{B}$ & Cat & $\mathrm{B}$ & $\mathrm{B}$ & & & $\mathrm{B}$ & Cat. & $\mathrm{B}$ & Cat & $\mathrm{B}$ & Cat. \\
\hline 77 & $\begin{array}{l}\text { Si Anak } \\
\text { Bogor }\end{array}$ & 5 & MS & 5 & MS & 5 & MS & 113 & $\begin{array}{l}\text { Pulu } \\
\text { Bolong }\end{array}$ & 4 & MR & 4 & MR & 4 & MR \\
\hline 78 & Si Lotik & 5 & MS & 5 & MS & 5 & MS & 114 & Pare Solo & 4 & MR & 5 & MS & 5 & MS \\
\hline 79 & $\begin{array}{l}\text { Si Pulo } \\
\text { Angkola }\end{array}$ & 5 & MS & 4 & MR & 5 & MS & 115 & $\begin{array}{l}\text { Pulut } \\
\text { Tomene }\end{array}$ & 3 & $\mathrm{R}$ & 5 & MS & 5 & MS \\
\hline & Si Pulo & & & & & & & 116 & Horeg & 2 & $\mathbf{R}$ & 4 & MR & 3 & $\mathbf{R}$ \\
\hline 80 & Manda & & & & & & & 117 & Majair & 3 & $\mathrm{R}$ & 4 & MR & 5 & MS \\
\hline & iling & 4 & MR & 4 & MR & 5 & MS & 118 & Kalimis & 5 & MS & 5 & MS & 4 & MR \\
\hline 81 & Putri Manis & 4 & MR & 5 & MS & 5 & MS & 119 & Termas & 6 & $\mathrm{~S}$ & 5 & MS & 5 & MS \\
\hline 82 & $\begin{array}{l}\text { Kuala Deli } \\
\text { Ramos }\end{array}$ & 5 & MS & 4 & MR & 5 & MS & 120 & $\begin{array}{l}\text { Daya Itoh } \\
\text { Rice } 4\end{array}$ & 6 & $\mathrm{~S}$ & 2 & $\mathrm{R}$ & 4 & MR \\
\hline 83 & Batu & 5 & MS & 5 & MS & 5 & MS & 121 & Si Gudang & 5 & MS & 4 & MR & 4 & MR \\
\hline & Mama & & & & & & & 122 & Cempo & 5 & MS & 4 & MR & 5 & MS \\
\hline 84 & Laka & 5 & MS & 5 & MS & 5 & MS & 123 & Gata & 5 & MS & 5 & MS & 5 & MS \\
\hline 85 & Wajo & & & & & & & 124 & Ringgit & 5 & MS & 5 & MS & 5 & MS \\
\hline 85 & Kuning & 5 & MS & 4 & MR & 5 & MS & 125 & Tampay & 5 & MS & 5 & MS & 5 & MS \\
\hline 86 & Sera & 4 & MR & 4 & MR & 5 & MS & 126 & Nolo kario & 4 & MR & 3 & $\mathrm{R}$ & 5 & MS \\
\hline 87 & Keakubi & 3 & $\mathrm{R}$ & 5 & MS & 5 & MS & 127 & Lumbu & 4 & MR & 3 & $\mathrm{R}$ & 5 & MS \\
\hline $\begin{array}{l}88 \\
89\end{array}$ & $\begin{array}{l}\text { Sehan } \\
\text { Ardas }\end{array}$ & $\begin{array}{l}5 \\
5\end{array}$ & $\begin{array}{l}\text { MS } \\
\text { MS }\end{array}$ & $\begin{array}{l}5 \\
4\end{array}$ & $\begin{array}{l}\text { MS } \\
\text { MR }\end{array}$ & $\begin{array}{l}5 \\
5\end{array}$ & $\begin{array}{l}\text { MS } \\
\text { MS }\end{array}$ & 128 & $\begin{array}{l}\text { Sri } \\
\text { Makmur }\end{array}$ & 4 & MR & 5 & MS & 5 & MS \\
\hline 90 & Apel & 5 & MS & 5 & MS & 5 & MS & 129 & Fajar & 5 & MS & 5 & MS & 5 & MS \\
\hline 91 & $\begin{array}{l}\text { Ndangan } \\
\text { Cantik } 1\end{array}$ & 5 & MS & 4 & MR & 5 & MS & 130 & $\begin{array}{l}\text { Kodok } \\
\text { Putih }\end{array}$ & 5 & MS & 5 & MS & 5 & MS \\
\hline 92 & $\begin{array}{l}\text { Lokal } \\
\text { buntu }\end{array}$ & & & & & & & 131 & $\begin{array}{l}\text { Cempo } \\
\text { Abang ner }\end{array}$ & 5 & MS & 5 & MS & 5 & MS \\
\hline & Sangala 2 & 5 & MS & 3 & $\mathrm{R}$ & 5 & MS & 132 & Teratai & 5 & MS & 5 & MS & 6 & $\mathrm{~S}$ \\
\hline & Pare & & & & & & & 133 & Banda & 5 & MS & 5 & MS & 5 & MS \\
\hline 93 & Pulunglia & 4 & MR & 3 & $\mathbf{R}$ & 4 & MR & 134 & Betonan & 6 & $\mathrm{~S}$ & 5 & MS & 6 & $\mathrm{~S}$ \\
\hline 94 & Cere Gelas & 5 & MS & 4 & MR & 5 & MS & 135 & Lumut & 6 & $\mathrm{~S}$ & 5 & MS & 6 & $\mathrm{~S}$ \\
\hline 95 & $\begin{array}{l}\text { Kembang } \\
\text { Ading }\end{array}$ & 5 & MS & 5 & MS & 4 & MR & 136 & $\begin{array}{l}\text { Sunting } \\
\text { Beringin }\end{array}$ & 6 & $\mathrm{~S}$ & 5 & MS & 5 & MS \\
\hline $\begin{array}{l}96 \\
97\end{array}$ & $\begin{array}{l}\text { Limar } \\
\text { Sasak Jalan }\end{array}$ & $\begin{array}{l}5 \\
5\end{array}$ & $\begin{array}{l}\text { MS } \\
\text { MS }\end{array}$ & $\begin{array}{l}5 \\
5\end{array}$ & $\begin{array}{l}\text { MS } \\
\text { MS }\end{array}$ & $\begin{array}{l}5 \\
5\end{array}$ & $\begin{array}{l}\text { MS } \\
\text { MS }\end{array}$ & 137 & $\begin{array}{l}\text { Siak } \\
\text { Simpur }\end{array}$ & 5 & MS & 5 & MS & 5 & MS \\
\hline 98 & $\begin{array}{l}\text { Popot } \\
\text { Kembang }\end{array}$ & 5 & MS & 5 & MS & 5 & MS & 138 & $\begin{array}{l}\text { Bendang } \\
\text { Bujur }\end{array}$ & 5 & MS & 5 & MS & 5 & MS \\
\hline 100 & $\begin{array}{l}\text { Singkan } \\
\text { Ketan Siam }\end{array}$ & $\begin{array}{l}5 \\
5\end{array}$ & $\begin{array}{l}\text { MS } \\
\text { MS }\end{array}$ & $\begin{array}{l}5 \\
5\end{array}$ & $\begin{array}{l}\text { MS } \\
\text { MS }\end{array}$ & $\begin{array}{l}4 \\
5\end{array}$ & $\begin{array}{l}\text { MR } \\
\text { MS }\end{array}$ & 139 & $\begin{array}{l}\text { Kuku } \\
\text { Balam }\end{array}$ & 5 & MS & 5 & MS & 5 & MS \\
\hline 101 & $\begin{array}{l}\text { Uyun } \\
\text { Kwatik }\end{array}$ & 5 & MS & 4 & MR & 6 & $\mathrm{~S}$ & 140 & $\begin{array}{l}\text { Sirandah } \\
\text { Tjogok }\end{array}$ & 5 & MS & 5 & MS & 6 & $\mathrm{~S}$ \\
\hline 102 & Tinggi & 5 & MS & 4 & MR & 6 & $\mathrm{~S}$ & 141 & Empat & 4 & MR & 5 & MS & 5 & MS \\
\hline 103 & Rumbai & & & & & & & 142 & Padi Rasi & 5 & MS & 5 & MS & 6 & $\mathrm{~S}$ \\
\hline 103 & $\begin{array}{l}\text { ayam } \\
\text { Padi }\end{array}$ & 5 & MS & 5 & MS & 5 & MS & 143 & $\begin{array}{l}\text { Djula Djuli } \\
\text { A }\end{array}$ & 5 & MS & 5 & MS & 6 & $\mathrm{~S}$ \\
\hline 104 & Rantau & & & & & & & 144 & Hoing & 4 & MR & 5 & MS & 5 & MS \\
\hline & Undik & 5 & MS & 4 & MR & 5 & MS & 145 & Makmur & 4 & MR & 5 & MS & 5 & MS \\
\hline 105 & Cinta & & & & & & & 146 & Revolusi & 3 & $\mathrm{R}$ & 5 & MS & 5 & MS \\
\hline 106 & Kasih & 4 & MR & 4 & MR & 5 & MS & 147 & Gropak & 4 & MR & 5 & MS & 5 & MS \\
\hline $\begin{array}{l}106 \\
107\end{array}$ & $\begin{array}{l}\text { Padi Bugis } \\
\text { Surya }\end{array}$ & $\begin{array}{l}5 \\
5\end{array}$ & $\begin{array}{l}\text { MS } \\
\text { MS }\end{array}$ & $\begin{array}{l}4 \\
4\end{array}$ & $\begin{array}{l}\text { MR } \\
\text { MR }\end{array}$ & $\begin{array}{l}4 \\
4\end{array}$ & $\begin{array}{l}\text { MR } \\
\text { MR }\end{array}$ & 148 & $\begin{array}{l}\text { Serung } \\
\text { Itun }\end{array}$ & 5 & MS & 5 & MS & 5 & MS \\
\hline 108 & $\begin{array}{l}\text { Beras } \\
\text { merah }\end{array}$ & 5 & MS & 5 & MS & 5 & MS & 149 & $\begin{array}{l}\text { Nangka } \\
\text { Bosok }\end{array}$ & 4 & MR & 5 & MS & 5 & MS \\
\hline 109 & Slereng & 5 & MS & 5 & MS & 5 & MS & 150 & Bengawan & 5 & MS & 5 & MS & 5 & MS \\
\hline 110 & Pae Laguh & 5 & MS & 6 & $\mathrm{~S}$ & 4 & MR & 151 & Sijem & 4 & MR & 4 & MR & 3 & $\mathbf{R}$ \\
\hline 111 & $\begin{array}{l}\text { Ketan } \\
\text { Jambruk }\end{array}$ & 4 & MR & 5 & MS & 5 & MS & 152 & $\begin{array}{l}\text { Sampa } \\
\text { kiring }\end{array}$ & 4 & MR & 5 & MS & 5 & MS \\
\hline 112 & Sate Liko & 3 & $\mathbf{R}$ & 3 & $\mathbf{R}$ & 3 & $\mathbf{R}$ & 153 & Pelopor & 3 & $\mathrm{R}$ & 5 & MS & 5 & MS \\
\hline
\end{tabular}




\begin{tabular}{|c|c|c|c|c|c|c|c|}
\hline \multirow[t]{2}{*}{ No. } & \multirow{2}{*}{$\begin{array}{l}\text { Accession } \\
\text { Name }\end{array}$} & \multicolumn{2}{|c|}{$\begin{array}{l}\text { Xoo } \\
1110\end{array}$} & \multicolumn{2}{|c|}{$\begin{array}{l}\text { Xoo } \\
1122\end{array}$} & \multicolumn{2}{|c|}{$\begin{array}{l}\text { Xoo } \\
1130\end{array}$} \\
\hline & & B & Cat. & B & Cat & B & Cat. \\
\hline 154 & $\begin{array}{l}\text { Cempo } \\
\text { Slamet }\end{array}$ & 4 & MR & 5 & MS & 6 & $\mathrm{~S}$ \\
\hline 155 & Ketan Uis & 5 & MS & 5 & MS & 5 & MS \\
\hline 156 & Loyang & 5 & MS & 5 & MS & 5 & MS \\
\hline 157 & Jerah & 4 & MR & 5 & MS & 5 & MS \\
\hline 158 & $\begin{array}{l}\text { Ketan } \\
\text { Wangi }\end{array}$ & 5 & MS & 5 & MS & 5 & MS \\
\hline 159 & Marus & 5 & MS & 5 & MS & 5 & MS \\
\hline 160 & $\begin{array}{l}\text { Koneng } \\
\text { Gundil }\end{array}$ & 5 & MS & 5 & MS & 5 & MS \\
\hline
\end{tabular}

\begin{tabular}{|c|c|c|c|c|c|c|c|}
\hline \multirow[t]{2}{*}{ No. } & \multirow{2}{*}{$\begin{array}{l}\text { Accession } \\
\text { Name }\end{array}$} & \multicolumn{2}{|c|}{$\begin{array}{l}\text { Xoo } \\
1110 \\
\end{array}$} & \multicolumn{2}{|c|}{$\begin{array}{l}\text { Xoo } \\
1122 \\
\end{array}$} & \multicolumn{2}{|c|}{$\begin{array}{l}\text { Xoo } \\
1130 \\
\end{array}$} \\
\hline & & B & Cat. & B & Cat & B & Cat. \\
\hline 161 & $\begin{array}{l}\text { Sirandah } \\
\text { Lunto }\end{array}$ & 3 & $\mathrm{R}$ & 5 & MS & 5 & MS \\
\hline 162 & Cisadane & 3 & $\mathrm{R}$ & 5 & MS & 4 & MR \\
\hline 163 & Semeru & 4 & MR & 5 & MS & 5 & MS \\
\hline 164 & IRBB7 & 1 & HR & 1 & HR & 3 & $\mathrm{R}$ \\
\hline 165 & IR24 & 5 & MS & 5 & MS & 5 & MS \\
\hline 166 & Conde & 1 & HR & 2 & $\mathrm{R}$ & 3 & $\mathrm{R}$ \\
\hline 167 & $\begin{array}{l}\text { Kencana } \\
\text { Bali }\end{array}$ & 5 & MS & HS & HS & 5 & MS \\
\hline
\end{tabular}

Note: B: BLB Score: $1-9$ (Resistant: $1-4$ and Susceptible: 5- 9)

Cat:: Category: HR: Highly Resistant; R: Resistant; MR: Medium Resistant, MS: Medium Susceptible, S: Susceptible; HS: Highly Susceptible 


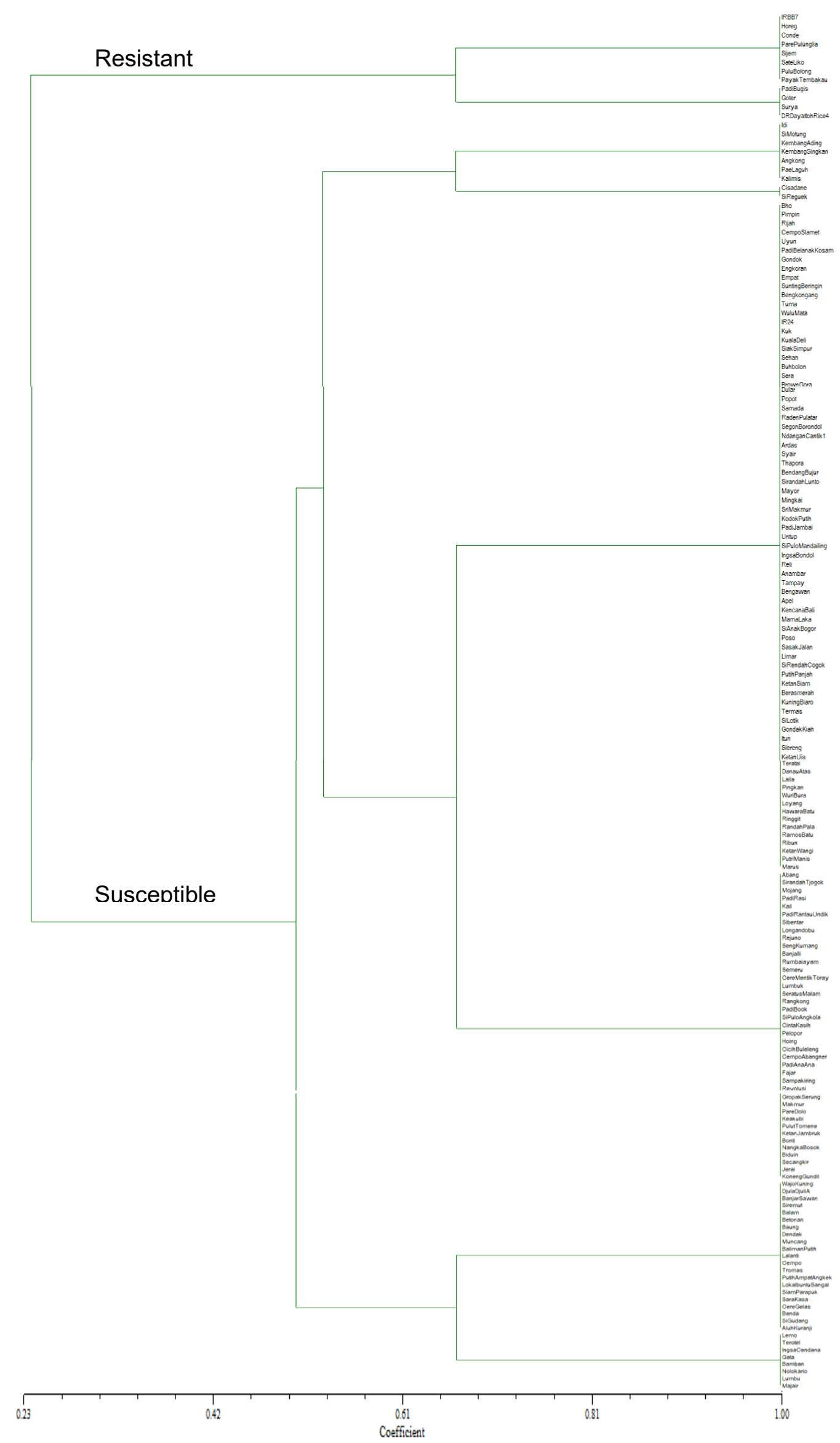

Figure 1. UPGMA Clustering analysis of 167 Indonesian rice germplasms based on their resistance to the three isolates/pathotypes tested. 


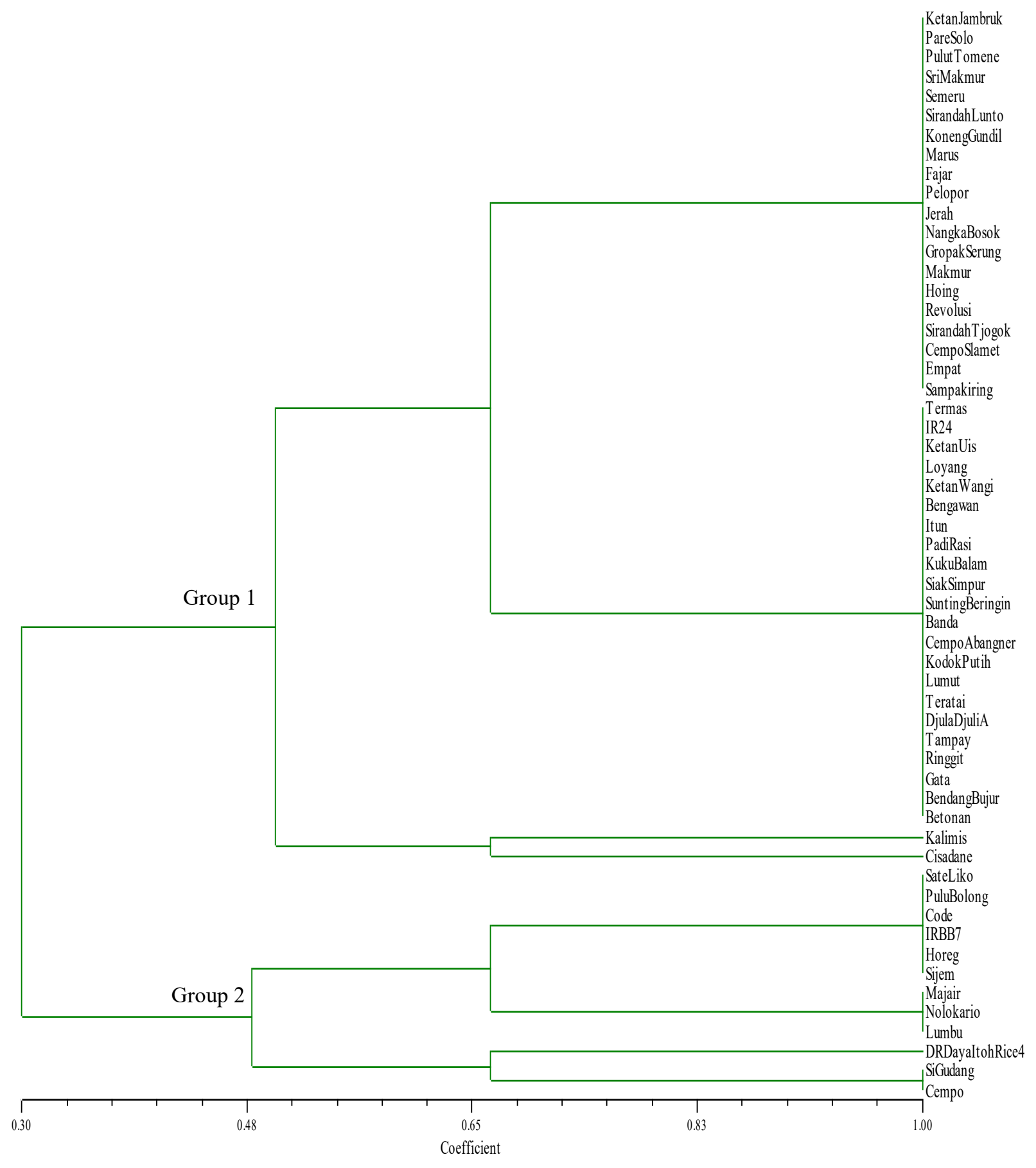

Figure 2. UPGMA tree of 56 Indonesian rice accessions using eight $\mathrm{Xa} 7$ resistance-gene-linked SSR markers on chromosome 6, clustered as two major groups. Group 1 represents the susceptible varieties as indicated by IR24 as the susceptible control (black box). Group 2 represents the resistant varieties indicated by IRBB7 and Conde. 